\title{
Influence of biodiesel blending on physicochemical properties and importance of mathematical model for predicting the properties of biodiesel blend
}

\author{
M.A. Wakil ${ }^{\text {a,* }}$, M.A. Kalam ${ }^{\text {a }}$, H.H. Masjuki ${ }^{\text {a }}$, A.E. Atabani ${ }^{\text {b }}$, I.M. Rizwanul Fattah ${ }^{\text {a }}$ \\ ${ }^{a}$ Center for Energy Sciences, Department of Mechanical Engineering University of Malaya, 50603 Kuala Lumpur, Malaysic \\ ${ }^{\mathrm{b}}$ Department of Mechanical Engineering, Faculty of Engineering, Erciyes University, 38039 Kayseri, Turkey
}

A R T I C L E I N F O

Article history:

Received 24 October 2014

Accepted 16 January 2015

Available online 6 February 2015

\section{Keywords:}

Biodiese

Edible oil

Non-edible oil

Blending

Physicochemical properties

Mathematical modeling

\begin{abstract}
A B S T R A C T
The growing demand for green world serves as one of the most significant challenges of modernization. Requirements like largest usage of energy for modern society as well as demand for friendly milieu create a deep concern in field of research. Biofuels are placed at the peak of the research arena for their underlying benefits as mentioned by multiple researches. Out of a number of vegetable oils, only a few are used commercially for biodiesel production. Due to various limitations of edible oil, non-edible oils are becoming a profitable choice. Till today, very little percentage of biodiesel is used successfully in engine. The research is still continuing for improving the biodiesel usage level. Recently, it is found that the blended biodiesel from more than one feedstock provides better performance in engine. This paper reviews the physicochemical properties of different biodiesel blends obtained from various feedstocks with a view to properly understand the fuel quality. Moreover, a short description of each feedstock is given along with graphical presentation of important properties for various blend percentages from B0 to B100. Finally, mathematical model is formed for predicting various properties of biodiesel blend with the help of different research data by using polynomial curve fitting method. The results obtained from a number of literature based on this work shows that the heating value of biodiesel is about $11 \%$ lower than diesel except coconut (14.5\% lower) whereas kinematic viscosity is in the range of $4-5.4 \mathrm{~mm}^{2} / \mathrm{s}$. Flash point of all biodiesels are more than $150^{\circ} \mathrm{C}$, except neem and coconut. Cold flow properties of calophyllum, palm, jatropha, moringa are inferior to others. This would help to determine important properties of biodiesel blend for any percentage of biodiesel and to select the proper feedstock for better performance.
\end{abstract}

(c) 2015 Elsevier Ltd. All rights reserved.

\section{Introduction}

The primary catalyst of any country's socio-economic development is energy. However, through modernization the demand of energy consumption is facing a serious threat due to the gradual declination of fossil fuels. Various sectors for instance, industry, transport, agriculture, domestic sector, etc. require energy from sources like wood, coal, petroleum products, nuclear power, solar, and wind [1]. Currently, more than $80 \%$ of energy demand is catered by fossil fuels [2]. The deep concern about fossil fuels is that it's generation of toxic pollutants links to global warming, climate change and even some impasse diseases [3]. To compete with this critical situation, a good number of research have been

\footnotetext{
* Corresponding author. Tel.: +60 163269524

E-mail addresses: wakil_01@yahoo.com (M.A. Wakil), kalam@um.edu.my (M.A. Kalam).

http://dx.doi.org/10.1016/j.enconman.2015.01.043

0196-8904/○ 2015 Elsevier Ltd. All rights reserved.
}

conducted to find alternative to fossil fuels for eco-friendly condition.

Biodiesel is considered to be a notable option for at least complementing conventional fuels [3]. Its production from renewable sources such as vegetable oils and fats has been widely reviewed [4-10]. It is advantageous over petroleum product because it is safe in handling, biodegradable, non-toxic, has higher combustion efficiency, higher cetane number, contains no sulfur, etc. [1,3,11-14]. In addition, it is advantageous for numerous social benefits like rural revitalization, creation of new jobs and reduced global warming [15].

Among the available sources of biodiesel, edible oils are dominating in several countries as diesel substitute. For instance, canola and soybean are used in USA, palm oil in Malaysia, rapeseed oil in Europe etc. [12,14]. Currently, more than $95 \%$ of the world biodiesel comes from edible oil. In the year 2004-2007 the edible oil used for biodiesel production was 6.6 million tons which would attribute $34 \%$ of the increase in global consumption of biodiesel and 


\section{Nomenclature}

APME Aphanamixis polystachya methyl ester

CIME Calophyllum inophyllum methyl ester

COME Coconut methyl ester

CME Canola methyl ester

CMME Croton megalocarpus methyl ester

JCME Jatropha curcas methyl ester

MOME Moringa oleifera methyl ester

NME Neem methyl ester

POME Palm methyl ester

RBME Rice bran methyl este
SME Sesame methyl ester

SFME Sterculia foetida methyl ester

CB10 Calophyllum biodiesel (10\% + Diesel 90\%) blend

$\mathrm{COB} \quad$ Coconut biodiesel, diesel blend

$\mathrm{CrB} \quad$ Croton biodiesel, diesel blend

JB Jatropha biodiesel, diesel blend

CP Cloud point

PP Pour point

CFPP Cold filter plugging point also lead to one third of the total projected growth of edible oils between 2005 and 2017 [16]. This large usage of edible oils for biodiesel has caused a serious impact on food supply. It has the ability to lead to starvation especially in developing countries and impose antagonistic effect on environment [13]. The prominent solution is to use second generation feedstocks (non-edible oils) which has higher potential for biodiesel production [13] and can easily eliminate the food vs fuel concern. Another boosting feedstock is algae. Although full scale commercialization from algae has not begun yet, but it is expected to be rich in oil content (oil content in microalgae can exceed $80 \%$ of its weight of dry biomass) [3].

The use of vegetable oils started more than a century ago. Apart from the remarkable advantages, biodiesel has couple of difficulties to be used as a replacement of fossil fuels in engine such as high viscosity and density and low volatility and heating value [12]. These difficulties lead to problems in pumping, atomization, gumming, injection fouling, piston ring sticking, etc. [1]. Another serious threat for biodiesel industry is the cost of feedstock which currently accounts for over $70-85 \%$ of biodiesel production cost $[13,17,18]$. One solution to alleviate this problem is to use multiple feedstocks of varying percentage. It will not only subside the cost of production but also enhance product quality. Problems of using edible oils can also be moderated by switching these with non-edible oils. It has been proven that biodiesel containing up to B5 will have no notable difference in terms of power and fuel economy when it is compared to diesel [19]. ASTM D7467 suggests blending of $20 \%$ biodiesel with diesel. In 2014, the Chevy Cruze Clean Turbo Diesel is directing the engine with rated $\mathrm{B} 20$ biodiesel compatibility [20]. Now-a-days research is going on to increase the use of biodiesel blending with diesel. Consequently, biodiesel blending (biodiesel and diesel) bring a new topic in research arena. A number of researches have been undertaken already on biodiesel blending [17,21-27]. Accordingly, it has become easier to have a clear concept of the physicochemical properties of edible and non-edible vegetable oils with varying blending percentages for a better understanding on blend qualities. Survey of existing literature shows that most of the studies focus on pure biodiesel properties rather than properties of blending. Therefore, this review aims firstly at focusing on the physicochemical properties of edible and non-edible biodiesel and their blends with diesel (B0-B100). Secondly, mathematical equation for various biodiesel blends would be produced in order to predict the important properties of blended biodiesel for any percentage of biodiesel. Here, a polynomial curve fitting method is used to generate the equation. It is believed that such kind of studies will assist researchers for further study about optimal usage of biodiesel.

\section{Biodiesel feedstocks}

Feedstock-related cost has been regarded as a primary obstacle as it constitutes roughly around $60-90 \%$ of the total biodiesel production cost [28]. Biodiesel can be produced from a wide variety of oils. These include vegetable oils (edible and non-edible oils) [13,29-34], food processing waste (waste cooking oils, animal fat (tallow, lard, yellow grease, chicken fat) [28,35-37]), industrial residues) [38], algae, halophytes (Salicomia bigelovii [39]), sewage sludge [40], etc.

Globally, more than 350 oil-bearing crops have been identified as potential biodiesel sources $[12,13,29,41]$. The regional climate mainly affects the feedstock selection for biodiesel production [13]. Table 1 presents some important oil bearing species $[1,2,8,13,14,16,29,42]$

A concise description of some edible and non-edible oil plants including their country of origin, oil content and their necessary uses are portrayed in Table 2 with their fatty acid composition in Table 3. The identification of plants and seeds of the selected oil sources are shown in Fig. 1.

\section{Characteristics of crude oils and biodiesels}

Characterization of oil properties is necessary to research abou the processing of crude oil to biodiesel and afterwards to diesel engine successfully. The physical and chemical properties of any fuel are significant factors which help to decide whether the oil

Table 1

Oil species for biodiesel production.

\begin{tabular}{|c|c|}
\hline Category & Source of oil \\
\hline Edible oil & $\begin{array}{l}\text { Sunflower, Rapeseed, Rice bran, Soybean, Coconut, Corn, Palm, Olive, Pistachia Palestine, Sesame seed, Peanut, Opium Poppy, Safflower oil, Amaranth, } \\
\text { apricot, argan, artichoke, avocado, babassu, bay laurel, beech nut, ben, Borneo tallow nut, carob pod (algaroba), cohune, coriander seed, false flax, grape } \\
\text { seed, hemp, kapok seed, lallemantia, lemon seed, macauba fruit (Acrocomia sclerocarpa), meadowfoam seed, mustard, okra seed (hibiscus seed), perilla } \\
\text { seed, pequi,(Caryocar brasiliensis seed), pine nut, poppy seed, prune kernel, quinoa, ramtil (Guizotia abyssinica seed or Nigerpea), rice bran, tallow, tea } \\
\text { (camellia), thistle (Silybum marianum seed), and wheat germ }\end{array}$ \\
\hline $\begin{array}{l}\text { Non-edible } \\
\quad \text { oil }\end{array}$ & $\begin{array}{l}\text { Jatropha, Karanjaor Pongamia, Neem, Jojoba, Cottonseed, Linseed, Mahua, Deccan hemp, Kusum, Orange, Rubbe rseed, Sea Mango, Karanja or Honge, } \\
\text { milk bush, Nagchampa, Rubber seed tree, Tobacco seed oil, Algae, Halophytes and Xylocarpus moluccensis }\end{array}$ \\
\hline \multicolumn{2}{|c|}{ Waste or recycled oil } \\
\hline
\end{tabular}


Table 2

\begin{tabular}{|c|c|c|c|c|c|c|c|}
\hline \multirow[t]{2}{*}{ Name of oil } & \multirow[t]{2}{*}{ Characteristics } & \multirow[t]{2}{*}{ Country of available } & \multirow[t]{2}{*}{$\begin{array}{l}\text { Oil } \\
\text { content }\end{array}$} & \multicolumn{2}{|c|}{$\begin{array}{l}\text { Yield of } \\
\text { plant seed }\end{array}$} & \multirow[t]{2}{*}{ Uses } & \multirow[t]{2}{*}{ Refs. } \\
\hline & & & & $\begin{array}{l}\mathrm{kg} / \mathrm{l} \\
\text { tree }\end{array}$ & $\mathrm{Kg} / \mathrm{ha}$ & & \\
\hline Aphanamixis polystachya & $\begin{array}{l}\text { Species in the family Meliaceae also known as pitraj tree. It is } \\
\text { indigenous as evergreen tree mainly growing in the tropical area of } \\
\text { Asia. This deciduous, perennial tree grows to } 20-30 \mathrm{~m} \text { long. Flower } \\
\text { clusters occur in leaf axils, less than a foot long. Seeds are greyish } \\
\text { brown. Flowering: May-September }\end{array}$ & $\begin{array}{l}\text { A widespread species found in Indo-China and } \\
\text { western Malaysia. Indonesia, India, Bangladesh, } \\
\text { etc. }\end{array}$ & $\begin{array}{l}30- \\
40 \%\end{array}$ & $\begin{array}{l}25- \\
40\end{array}$ & & $\begin{array}{l}\text { Herbal medicine, potential for } \\
\text { biodiesel, The wood is used for } \\
\text { construction of ships, vehicles, posts } \\
\text { and agricultural tools }\end{array}$ & {$[43-47]$} \\
\hline Calophyllum inophyllum $\mathrm{L}$. & $\begin{array}{l}\text { Known as penaga laut, non-edible oil seed tree belongs to Clusiaceae } \\
\text { family. It enables to tolerate harsh environmental conditions (acidity, } \\
\text { salinity, and drought), require little maintenance, } 1000-4000 \mathrm{~mm} \\
\text { rainfall is sufficient per year. It is non-invasive, fruits profusely } \\
\text { (3000-10,000 seeds tree }{ }^{-1} \text { season }{ }^{-1} \text { ). Duration of harvest is two } \\
\text { months, Flowering in March-May and fruiting in October-November }\end{array}$ & $\begin{array}{l}\text { Native Australian tree, Found in tropical region } \\
\text { of India, Malaysia, Indonesia, Philippines, etc. }\end{array}$ & $\begin{array}{l}45- \\
70 \%\end{array}$ & $\begin{array}{l}25- \\
50\end{array}$ & 4680 & $\begin{array}{l}\text { For buming, timber, medicinal uses, } \\
\text { etc. }\end{array}$ & {$[13,47-50]$} \\
\hline Croton megalocarpus & $\begin{array}{l}\text { C. megalocarpus belongs to Euphorbiaceae family. It is a multipurpose } \\
\text { tree of Mexican and Central American origin with height } 15-40 \mathrm{~m} \text {. It } \\
\text { is capable to engender at the altitude of } 1200 \mathrm{~m} \text { and } 2450 \mathrm{~m} \\
\text { respectively. It requires less water footprint and fertilization during } \\
\text { cultivation stage }\end{array}$ & $\begin{array}{l}\text { The plant id indigenous to East Africa and } \\
\text { widely found in mountain of Tanzania, Kenya, } \\
\text { Uganda, etc. }\end{array}$ & $\begin{array}{l}40- \\
45 \%\end{array}$ & 50 & $\begin{array}{l}5000- \\
10,000\end{array}$ & $\begin{array}{l}\text { Rejuvenating chemical peels, pain } \\
\text { relieving and anti-inflammatory } \\
\text { drag, biodiesel production, etc. }\end{array}$ & {$[13,51-53]$} \\
\hline Coconut & $\begin{array}{l}\text { Coconut is member of the family Arecaceae. Found throughout the } \\
\text { tropic and sub-tropic area. It is familiar as large palm growing up to } \\
30 \mathrm{~m} \text { tall with pinnate leaves } 4-6 \mathrm{~m} \text { long. On very fertile land a } \\
\text { coconut tree can yield } 75 \text { fruits per year but often yield less than } 30 \\
\text { mainly due to tough cultural practices. Coconut palms are growing in } \\
\text { more than } 80 \text { countries of the world with a total production of } 61 \\
\text { million tons per year. Coconut trees are very hard to establish in dry } \\
\text { climates and cannot grow without frequent irrigation, in drought } \\
\text { conditions }\end{array}$ & $\begin{array}{l}\text { Indigenous to Indo-pacific origin. Philippines, } \\
\text { Indonesia, India, Thailand, Sri Lanka, Mexico, } \\
\text { Brazil etc. } \\
\end{array}$ & $60 \%$ & & & $\begin{array}{l}\text { Coconut oil is used for Skin } \\
\text { moisturizer, ingredient for soap, etc. }\end{array}$ & {$[1,54]$} \\
\hline Jatropha curcas & $\begin{array}{l}\text { J. curcas belongs to the family Euphorbiaceae. It grows throughout } \\
\text { most of the tropics and can survive on poor soil and drought } \\
\text { condition. It is reported as wild, semi-arid-climates plant. It flowers in } \\
\text { March-September and fruiting in April-May and October-November } \\
\text { of ellipsoidal green fruits. It produces seeds after } 12 \text { months and } \\
\text { reaches its maximum yield after } 4-5 \text { years. }\end{array}$ & $\begin{array}{l}\text { This plant is native to Mexico, Central America, } \\
\text { Africa, India, Brazil, Bolivia, Peru, Argentina, and } \\
\text { Paraguay }\end{array}$ & $\begin{array}{l}43- \\
59 \%\end{array}$ & $\begin{array}{l}0.5- \\
2.0\end{array}$ & $\begin{array}{l}100- \\
8000\end{array}$ & $\begin{array}{l}\text { Bio-fuels, carbon dioxide } \\
\text { sequestration, etc. }\end{array}$ & $\begin{array}{l}{[13,47,53,55-} \\
57]\end{array}$ \\
\hline Moringa oleifera & $\begin{array}{l}\text { Moringa oleifera is the most widely cultivated tree species in the } \\
\text { family of Moringaceae grows throughout most of the tropics. It is } \\
\text { drought tolerant and can survive in arid, harsh and infertilie land. The } \\
\text { tree can range from } 5 \text { to } 10 \mathrm{~m} \text { in height; sometimes can be even } 15 \mathrm{~m} \text {. } \\
\text { The plant starts bearing pods } 6-8 \text { months after planting }\end{array}$ & $\begin{array}{l}\text { Native to sub-Himalayan tracts of north-west } \\
\text { India, Africa, Latin America, Pakistan, } \\
\text { Bangladesh, Afghanistan, etc. }\end{array}$ & $\begin{array}{l}35- \\
45 \%\end{array}$ & & 3000 & $\begin{array}{l}\text { Moringa leaves uses as sources of } \\
\text { food, as forage for livestock, etc. }\end{array}$ & {$[53,58-60]$} \\
\hline Neem & $\begin{array}{l}\text { Neem (Azadirachta indica), a tree of mahogany family Meliaceae. It is } \\
\text { fast growing evergreen tree and can reach a height of } 15-20 \mathrm{~m} \text {, arely } \\
\text { to } 35-40 \mathrm{~m} \text {. It is drought tolerant, thrives in area with sub-arid to } \\
\text { sub-humid condition with annual rainfall } 400-1200 \mathrm{~mm} \text { and hardly } \\
\text { below } 400 \mathrm{~mm} \text {. This is a typical tropical to subtropical tree can } \\
\text { tolerate high to high temperature but cannot tolerate temperature } \\
\text { below } 4{ }^{\circ} \mathrm{C} \text {. Duration of harvest is } 2-3 \text { months. Flowering starts in } \\
\text { March-April and fruiting in June-July. The white, hard inner shell of } \\
\text { the fruits enclose with one and rarely two or three seeds }\end{array}$ & $\begin{array}{l}\text { Native to Asian countries like India, Pakistan, } \\
\text { Bangladesh, etc. }\end{array}$ & $\begin{array}{l}30- \\
39 \%\end{array}$ & $\begin{array}{l}20- \\
35\end{array}$ & & $\begin{array}{l}\text { Toiletries, pest control, cosmetics, } \\
\text { Pharmaceuticals, etc. }\end{array}$ & {$[47,61,62]$} \\
\hline Palm & $\begin{array}{l}\text { Palm oil tree belonging to the species namely, Elaeis guineensis. Oil } \\
\text { palms are originally from Western Africa, but can flourish wherever } \\
\text { heat and rainfall are abundant. It is found to be a tropical perennial }\end{array}$ & $\begin{array}{l}\text { Mostly available in South East Asia (Indonesia, } \\
\text { Malaysia), Thailand, Brazil, Nigeria, Colombia, } \\
\text { Ecuador, Costa Rica Venezuela, etc. }\end{array}$ & & & $\begin{array}{l}4000- \\
5000 \\
\text { (oil) }\end{array}$ & $\begin{array}{l}\text { Cooking ingredient, confectionery, } \\
\text { cosmetics, body products and } \\
\text { cleaning agents }\end{array}$ & {$[12,63-66]$} \\
\hline
\end{tabular}

Link to Full-Text Articles :

http://ac.els-cdn.com/S0196890415000473/1-s2.0-S0196890415000473-main.pdf?_tid=dd54ded2-f3a1-11e4a79e-00000aacb362\&acdnat $=1430883905$ c992a22816a8123b724ea782afcdddca 